\title{
Detection and Partial Characterization of Tenuiviruses from Black Spruce
}

\author{
J. D. Castello, Professor, S. O. Rogers, Associate Professor, G. D. Bachand and R. C. Fillhart, former Graduate \\ Research Assistants, J. S. Murray, K. Weidemann, M. Bachand, and M. A. Almond, former Undergraduate Re- \\ search Assistants, State University of New York, College of Environmental Science and Forestry, 1 Forestry Drive, \\ Syracuse 13210-2788
}

\begin{abstract}
Castello, J. D., Rogers, S. O., Bachand, G. D., Fillhart, R. C., Murray, J. S., Weidemann, K., Bachand, M., and Almond, M. A. 2000. Detection and partial characterization of tenuiviruses from black spruce. Plant Dis. 84:143-147.

Filamentous viral ribonucleoproteins (RNPs) 12 to $16 \mathrm{~nm}$ in diameter and 100 to $1,260 \mathrm{~nm}$ in length, and characteristic of the genus Tenuivirus, were detected by transmission electron microscopy in purified extracts of needles collected from two mature, asymptomatic black spruce (Picea mariana) trees in New York, but not in extracts of needles from nursery seedlings. Purified RNPs from one tree had a buoyant density in $\mathrm{CsCl}=1.39 \mathrm{~g} / \mathrm{cm}^{3}$ and an $A_{260 / 280}=1.436$. Four ssRNA segments of $1.3,2.1,2.3$, and $3.5 \mathrm{~kb}$, but not the 8 - to 9-kb fragment characteristic of most tenuiviruses, were detected in purified RNA extracts. Amplification products of the expected size were observed when RNA extracts from the two spruce trees and Maize stripe tenuivirus (MStpV), but not from tobacco, Chenopodium quinoa, or spruce seedlings were subjected to reverse transcription-polymerase chain reaction (RT-PCR) using primers to the $\mathrm{p} 3$ open reading frame (ORF) of MStpV vRNA 3. However, only MStpV amplified when primers to the nucleocapsid ORF (pc3 ORF on vcRNA 3) were used. Similarly, only MStpV amplified by immunocapture polymerase chain reaction (PCR) using antiserum to MStpV and primers to the p3 ORF. Sequence comparisons suggest that two distinct tenuiviruses occur in black spruce, one more closely related to MStpV than the other. One of these tenuiviruses was detected in one of 10 additional black spruce trees tested, but not in trees of six other coniferous species sampled in the Adirondack Mountains of New York.
\end{abstract}

Additional keywords: Rice hoja blanca virus, Rice stripe virus

Conifers are hosts of known as well as unidentified viruses. Characterization and identification of viruses are problematic due to the inherent difficulties encountered in purification from coniferous hosts or transmission to herbaceous hosts. To date, only Tomato mosaic tobamovirus (ToMV) has been detected in a coniferous forest tree species (red spruce, Picea rubens), transmitted to herbaceous hosts, characterized, identified, back-transmitted, and significant effects on conifer growth and development observed (1). However, uncharacterized viruslike particles (VLPs) have been detected frequently in many coniferous forest tree species, including Scots pine (Pinus sylvestris) (2), Norway spruce (Picea abies) (4), and balsam fir (Abies balsamea) (J. D. Castello, unpublished). Flachmann et al. (6) detected icosahedral VLPs of two different sizes in European silver fir (Abies alba) and six other Abies spp., but not in other coniferous genera tested. These VLPs failed to

Corresponding author: J. D. Castello

E-mail: jdcastel@syr.edu

Accepted for publication 5 October 1999.

Publication no. D-1999-1130-01R

(C) 2000 The American Phytopathological Society react with antisera to 17 different plant viruses representing several taxonomic groups and were not transmissible to herbaceous hosts.

In recent attempts to detect ToMV in various coniferous hosts, we observed filamentous viral ribonucleoprotein particles (RNP) resembling those of the genus Tenuivirus in clarified extracts of needles collected from black spruce (Picea mariana) trees in New York. Tenuiviruses are nonenveloped plant viruses with a genome consisting of four to five species of ambiand negative sense ssRNA. The RNPs are filamentous and of indeterminate length, 3 to $12 \mathrm{~nm}$ in diameter, and of linear, circular, helical, or supercoiled configuration $(5,7)$. The group consists of five definitive members with relatively narrow host ranges within the grasses, and they are persistently transmitted by Delphacid planthoppers, in which the viruses are transovarially transmitted. Rice grassy stunt virus (RGSV) is distributed throughout the rice-growing regions of Asia; Rice hoja blanca virus (RHBV) occurs in South and Central America; Maize stripe virus (MStpV) has been reported in Africa, Central America, and Florida in the United States (16); European wheat striate mosaic virus (EWSMV) occurs throughout Europe and Scandinavia; and the type member, Rice stripe virus (RSV), with the widest host range among the tenuiviruses, occurs throughout eastern Asia and the Pacific Islands (7).

Our objectives were to characterize the RNPs purified from black spruce and to determine if they are tenuiviruses. We hypothesize that two distinct tenuiviruses occur in black spruce in New York. A preliminary report has been published (3).

\section{MATERIALS AND METHODS}

Tissue collection. Branches with needles were collected in February, June, and August 1995, February 1996, and February and September 1997 from an asymptomatic black spruce tree located approximately $2 \mathrm{~km}$ from Middle Settlement Lake near Old Forge, New York $\left(43^{\circ} 41^{\prime} 15^{\prime \prime} \mathrm{N}\right.$ and $\left.75^{\circ} 04^{\prime} 30^{\prime \prime} \mathrm{W}\right)$. The tree is approximately $30 \mathrm{~cm}$ diameter at breast height (dbh) and $10 \mathrm{~m}$ tall. In addition, needles were collected in July 1996 and November 1997 from another asymptomatic tree approximately $10 \mathrm{~cm}$ dbh and $5 \mathrm{~m}$ tall located in a plantation at the SUNY-ESF Experiment Station, Syracuse, New York. Needles also were collected from 3-yearold black spruce seedlings at the Experiment Station in May 1995 and from 10 dormant, container-grown, 3-year-old seedlings obtained from the Canadian Forest Service (St. Foy, Quebec, Canada) in March 1997. Current-season and 1-yearold needles were stripped from the branches and stored in plastic freezer bags at $-20^{\circ} \mathrm{C}$ until subjected to purification or RNA extraction.

Purification and characterization. Eighty-gram aliquots of needles from the trees located at Old Forge and Syracuse and from the seedlings at the college nursery were subjected to the virus purification protocol of Flachmann et al. (6). In an attempt to improve yield, several $80-\mathrm{g}$ needle aliquots from the Old Forge tree also were subjected to purification protocols for MStpV (8) and RHBV (12).

Virus yield was estimated using the extinction coefficient of RSV ( $\mathrm{E}_{260} @ 0.1 \%$ 4). Final pellet suspensions of 1 to 10 purified preparations of needles collected from the tree at Old Forge were combined and subjected to isopycnic density-gradient centrifugation in $\mathrm{CsCl}$ in water at $20^{\circ} \mathrm{C}$ on five separate occasions.

Chenopodium quinoa and corn (Zea mays) cultivars Twice as Nice and Ornamental Popcorn were mechanically inoculated with final pellets from several purifi- 
cations suspended in $10 \mathrm{mM}$ phosphate buffer ( $\mathrm{pH}$ 8.0). Plants were placed in a greenhouse and monitored for symptom development for 3 weeks.

Electron microscopy. Formvar-fronted, carbon-coated, 400-mesh nickel grids were floated on $10-\mu \mathrm{l}$ drops of purified virus preparations and incubated for $5 \mathrm{~min}$. The grids were washed with 20 drops of 100 $\mathrm{mM}$ phosphate buffer $(\mathrm{pH} 7.4)$, followed by 40 drops of sterile deionized water, and negatively stained with 30 drops of $2 \%$ aqueous uranyl acetate ( $\mathrm{pH}$ 4.0). Grids were viewed with a JEOL 100 EX transmission electron microscope at $80 \mathrm{KV}$. Length and diameter of 100 particles were measured.

RNA gel electrophoresis. RNA was extracted using the protocol of Tavantzis (15) from two combined purified preparations from needles collected from the tree at Old Forge. Approximately $20 \mu \mathrm{g}$ of RNA was electrophoresed on a $1 \%$ agarose-formaldehyde gel according to the basic protocol of Kingston (11). RNA ladders $(0.24$ to $9.5 \mathrm{kbp})$ were used as molecular weight markers. Following electrophoresis and visualization of bands with ultraviolet light, the gel was photographed and then exposed to RNase A in the presence of $300 \mathrm{mM}$ sodium chloride.

RNA extraction. Total cellular RNA was extracted from 0.2 -g aliquots of needles from the trees at Old Forge and Syracuse, from 10 container-grown black spruce seedlings raised from seed from the Canadian Forestry Service, from MStpVinfected corn leaves (Florida isolate of the virus obtained from T. Lanker, formerly of the Ohio Agriculture Research \& Development Center, Wooster, $\mathrm{OH}$ ), and from healthy tobacco (Nicotiana glauca) and $C$. quinoa leaves. We employed the hot borate extraction method of Wilkins and Smart (17) modified to include a clarification step with phenol:chloroform:isoamyl alcohol following pellet suspension and washing with lithium chloride. Total RNA concentration and purity in each sample were determined by spectrophotometry.

Reverse transcription-polymerase chain reaction (RT-PCR) amplification and sequencing. For RT-PCR, two sets of nested primers were designed from vRNA 3 and vcRNA 3 of MStpV (GenBank accession 57426). The first set of primers was used to amplify a 536-bp product and a 399-bp nested product within the p3 ORF of MStpV. Forward primer 3-1 (5'-ACACAAAGTCCTGGGTAAAA-3', identical to bases 1 to 20) and reverse primer 3-2 (5'-CTTTCCATCATGGTCAGAGATTGG$3^{\prime}$, reverse complementary to bases 514 to 537) were used in the first round to amplify a 536-bp product, and forward primer 3-3 (5'-ACTTTTACACATCATCTGTTGGAGTG-3', identical to bases 71 to 96 ), and reverse primer 3-4 (5'-GGGACTTGGAAGGGTAGATTGT-3', reverse complementary to bases 449 to 470 ) were used in the second round to amplify a 399-bp nested product.

The second set of primers was designed to amplify a $1.1-\mathrm{kb}$ product and a $508-\mathrm{bp}$ nested product within the nucleocapsid protein (pc3) ORF of vcRNA-3 of MStpV. Reverse primer 3-5 (5'-TCTGGGTAATCGTTTAATCGATTTCG-3', reverse complementary to bases 2,324 to 2,349 ) and forward primer 3-6 (5'-AGTGCCAAACCATCTTATCCAACG-3', identical to bases 1,248 to 1,271 ) were used in the first round to amplify a $1.1-\mathrm{kb}$ product, and reverse primer 3-7 (5'-TGCAGGCTATGATGCGGCTA- $3^{\prime}$, reverse complementary to bases 2,117 to 2,136) and forward primer 3-8 (5'-GCAATCCTCTCTCCTTCTTTTTCGC-3', identical to bases 1,628 to 1,651 ) were used in the second round to amplify a 508-bp nested product.

The total cellular RNA extracts were subjected to RT-PCR using both sets of primers. RT was conducted in a $21-\mu \mathrm{l}$ mixture consisting of $8 \mu \mathrm{l}$ of sterile deionized water, $2 \mu \mathrm{l}$ of RNA, $1 \mu \mathrm{l}$ of RNase inhibitor (Boehringer-Mannheim Inc., Indianapolis, IN), and $1 \mu \mathrm{l}(10 \mu \mathrm{M})$ of primer 3-2 or 3-5. Following denaturation at $95^{\circ} \mathrm{C}$ for $5 \mathrm{~min}, 1 \mu \mathrm{l}$ of RNase inhibitor was added to each tube when the temperature fell below $60^{\circ} \mathrm{C}$. The tubes then were cooled on ice, and $7 \mu$ lof reagent mix $(5 \times$ 1st strand buffer [Gibco, Grand Island, NY], $10 \mathrm{mM}$ deoxynucleotide triphosphates [Sigma Chemical Co., St. Louis, $\mathrm{MO}$, and 0.1 $\mathrm{M}$ dithiothreitol) was added to each tube. RT was conducted at $42^{\circ} \mathrm{C}$ for $1 \mathrm{~h}$. When the thermocycler reached $42^{\circ} \mathrm{C}$, 200 units of Superscript II RNase H reverse transcriptase (Gibco) was added to each tube.

To amplify the $\mathrm{p} 3$ sequences, first-round PCR ( 45 cycles) was performed using $2 \mu \mathrm{l}$ of cDNA as follows: $95^{\circ} \mathrm{C}$ for $1 \mathrm{~min}, 52^{\circ} \mathrm{C}$ for $1 \mathrm{~min}, 72^{\circ} \mathrm{C}$ for $2 \mathrm{~min}$, and a final extension step of $10 \mathrm{~min}$ at $72^{\circ} \mathrm{C}$. Secondround nested PCR (45 cycles) was performed using 0.5 and $2.0 \mu \mathrm{l}$ of first-round product. PCR conditions were identical to the first round, except that the annealing temperature was raised to $60^{\circ} \mathrm{C}$. To amplify the pc3 sequences, both first- and second-round PCR were conducted as described above except that annealing temperatures of 45,55 , and $60^{\circ} \mathrm{C}$ were used. All PCR products were electrophoresed in $1.5 \%$ agarose gels in TBE for $2 \mathrm{~h}$ at $75 \mathrm{~V}$, stained with ethidium bromide, destained in water, and viewed with ultraviolet illumination.

Amplification products were cycle sequenced using a PRISM DNA sequencing kit with AmpliTaq polymerase (PerkinElmer Inc., DNA Applied Biosystems, Foster City, CA) and sent to the University of Montana for sequence determinations. The viral sequences that were detected in the black spruce trees at Old Forge and Syracuse, as well as the sequence of the $\mathrm{MStpV}$ isolate amplified in our laboratory, were aligned using the ClustalW program (Baylor College of Medicine, Molecular Biology Computational Resource) and compared with those of MStpV (GenBank accession M57426), RSV (accessions Y11095, D01094, X53563), and RHBV (accession L07940) by maximum parsimony analysis using a branch and bound search on PAUP* (14).

Immunocapture-reverse transcription PCR (IC-PCR). IC-PCR was conducted according to the basic protocol of Jacobi et al. (10). PCR tubes were coated with MStpV antiserum diluted 1:500. Samples were as follows: $0.1 \mathrm{~g}$ of needle tissue collected from the trees at Old Forge and Syracuse and tested separately, healthy bean (Phaseolus vulgaris) leaf tissue as a negative control, and MStpV-infected corn leaf tissue as a positive control. Leaf and needle tissues first were homogenized to a powder in liquid nitrogen and then extracted in PBS-TPO buffer (10) at dilutions of 1:10, 1:50, and 1:100. Reverse transcription (RT) and first-round PCR were conducted using primers 3-1 and 3-2. Firstround PCR (45 cycles) was conducted at an annealing temperature of $52^{\circ} \mathrm{C}$. A second round of PCR at an annealing temperature of $60^{\circ} \mathrm{C}$ was performed with $1 \mu \mathrm{l}$ of first-round product to amplify the nested 399-bp product using primers 3-3 and 3-4. All PCR products were electrophoresed as described above.

Preliminary assessment of virus prevalence and native host range. From May through July 1998, in conjunction with a survey to assess damage from a recent ice storm, needle tissue was collected from 40 randomly selected conifer trees (16 Picea rubens, 10 black spruce, five Abies balsamea, four Larix laricina, two Picea omorika, two Tsuga canadensis, and one Pinus strobus) in the Adirondack Mountain Park in New York State. Approximately $1 \mathrm{~g}$ each of current and 1-yearold needle tissues were collected from two branches per tree, placed in autoclaved microcentrifuge tubes, and transported on ice to the laboratory, where the samples were frozen at $-85^{\circ} \mathrm{C}$. Total RNA was extracted as described above by the method of Wilkins and Smart (17), followed by RT and two rounds of PCR as detailed above.

\section{RESULTS}

Physical and biological properties. Viral particles resembling tenuiviruses were observed in purified preparations from needles collected from the black spruce trees at Old Forge and Syracuse, but not from seedlings. Particles in a purified preparation from the tree at Old Forge subjected to isopycnic density-gradient centrifugation were filamentous and unbranched, and ranged in length from 100 to $1,260 \mathrm{~nm}$, with a diameter of approximately 12 to $16 \mathrm{~nm}$ (Fig. 1). The particles appeared to be fragmented, but end-to-end aggregation cannot be discounted. Virus 
yields were less than 1 to $3 \mathrm{mg} / \mathrm{kg}$ of needle tissue. Yield was not related to the season during which tissue was collected. However, based on transmission electron microscopy (TEM), purifications from fresh needles generally yielded more virus that appeared less fragmented than when tissue was stored at $-20^{\circ} \mathrm{C}$ for several months. Alternative tenuivirus purification protocols did not improve yield. Buoyant density of several different purified virus preparations from the tree at Old Forge ranged from 1.37 to 1.42 (mean $=1.391 \pm$ 0.02 ). The $A_{260 / 280}$ of virus preparations subjected to $\mathrm{CsCl}$ centrifugation was 1.436. Viruslike symptoms were not observed on mechanically inoculated corn or C. quinoa plants.

RNA gel electrophoresis. RNA bands corresponding to $1.3,2.1,2.3$, and $3.5 \mathrm{~kb}$ were observed in RNA extracted from virus purified from the Old Forge tree (data not shown). However, the $8.0-$ to $9.0-\mathrm{kb}$ band characteristic of most tenuiviruses was not observed. Bands were not observed following RNase A treatment under high salt conditions, indicating that they are single-stranded RNA. Comparison of sizes of RNA bands observed with those of known tenuiviruses is presented in Table 1.

RNA extraction. Total cellular RNA yield from spruce needles, corn, $N$. glauca, and $C$. quinoa leaves ranged from 30 to $500 \mu \mathrm{g} / \mathrm{g}$ of tissue weight, depending upon the plant species and whether the tissue was extracted fresh or frozen. Generally, tissues from herbaceous plants and those extracted when fresh yielded 10 times more RNA than spruce needles or frozen tissues. The mean $A_{260 / 280}$ of all RNA preparations was approximately 1.74 .

RT-PCR. Amplification products of the expected size were observed when RNA extracts from black spruce needles collected from the two trees at Old Forge and Syracuse, as well as MStpV RNA extracts, were subjected to two rounds of nested RTPCR using primers to the $\mathrm{p} 3$ ORF of RNA 3 of MStpV (Fig. 2). Only MStpV yielded detectable bands following one round of PCR. RNA extracts from tobacco, C. quinoa, and needles of 10 black spruce seedlings did not amplify (Fig. 2). Amplification products of the expected size were observed only for MStpV (in both rounds of PCR) when primers to the nucleocapsid ORF were used (data not shown). PCR products were not observed from RNA extracts of black spruce needles even when the annealing temperature was decreased to $45^{\circ} \mathrm{C}$.

An unrooted phylogram comparing MStpV, RHBV, and RSV RNA 3 sequences from GenBank to black spruce virus (BSV) sequences and a Florida isolate of MStpV amplified by MStpV primers to the p3 ORF of RNA 3 is shown in Figure 3. The tree is 269 steps $(\mathrm{CI}=0.93$, $\mathrm{RI}=0.91)$ and was generated using 314 nucleotide positions, including gaps (107

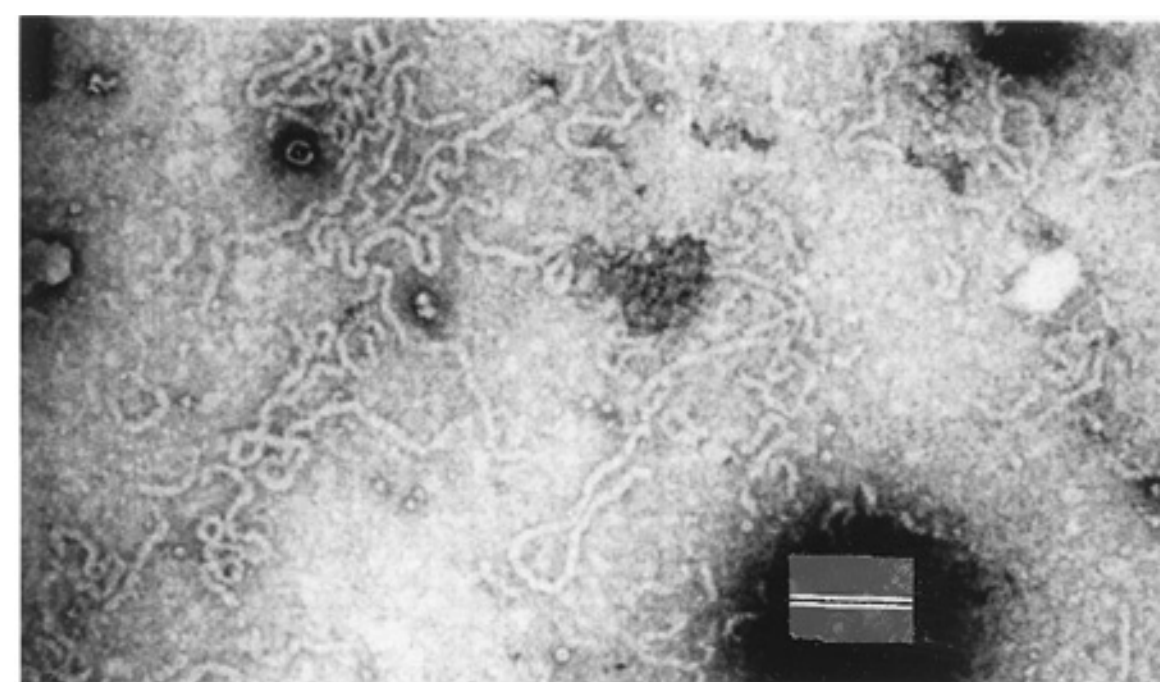

Fig. 1. Transmission electron photomicrograph of viruslike particles purified from needles collected from a black spruce tree located near Old Forge, New York, and subjected to isopycnic density gradient centrifugation. Bar $=200 \mathrm{~nm}$.

Table 1. Comparative genome sizes of four definitive members of the tenuivirus group of plant viruses: Rice stripe virus (RSV), Rice hoja blanca virus (RHBV), Rice grassy stunt virus (RGSV), Maize stripe virus (MStpV), and the virus purified from the black spruce tree near Old Forge, New York (BSV)

\begin{tabular}{lccccc}
\hline & \multicolumn{5}{c}{ Approximate size of RNA species $(\mathbf{k b})^{\mathbf{a}}$} \\
\cline { 2 - 5 } RNA species & RSV & RHBV & RGSV $^{\mathbf{b}}$ & MStpV & BSV \\
\hline 1 & 9.0 & $>9.0$ & ND $^{\mathrm{c}}$ & 8.0 & ND \\
2 & 3.5 & 3.6 & 4.4 & 3.3 & 3.5 \\
3 & 2.5 & 2.2 & 3.9 & 2.4 & 2.3 \\
4 & 2.5 & 2.0 & 3.6 & 2.2 & 2.1 \\
5 & ND & ND & 3.5 & 1.3 & 1.3 \\
\hline
\end{tabular}

a RSV, RHBV, and MStpV data from Falk and Tsai (5).

b RGSV data from Ramirez and Haenni (13).

ND $=$ not detected.

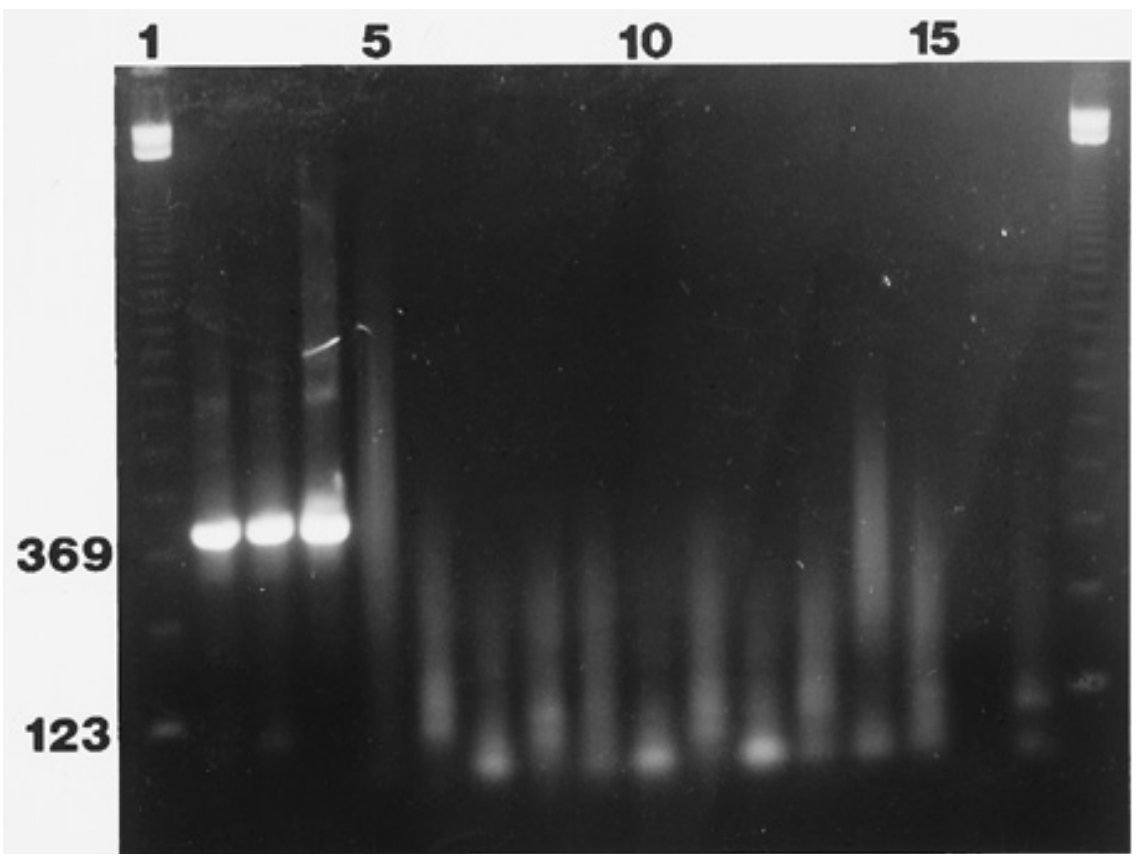

Fig. 2. Agarose gel electrophoresis of second-round reverse transcription-polymerase chain reaction (RT-PCR) amplification products from RNA extracts using primers to the p3 open reading frame of vRNA 3 of Maize stripe virus (MStpV). Lanes 1 and 18, 123-bp DNA ladder (first band is 123 bp); 2 and 3, RNA extracts from needles of black spruce trees located in Syracuse and Old Forge, New York; 4, RNA extract of corn leaf infected with MStpV; 5, RNA extract of healthy tobacco leaf; 6, RNA extract of healthy Chenopodium quinoa leaf; 7 to 16, RNA extracts from needles of 10 black spruce seedlings; and 17, deionized and autoclaved distilled water. Note absence of pathogen bands in lanes 5 to 17 . 


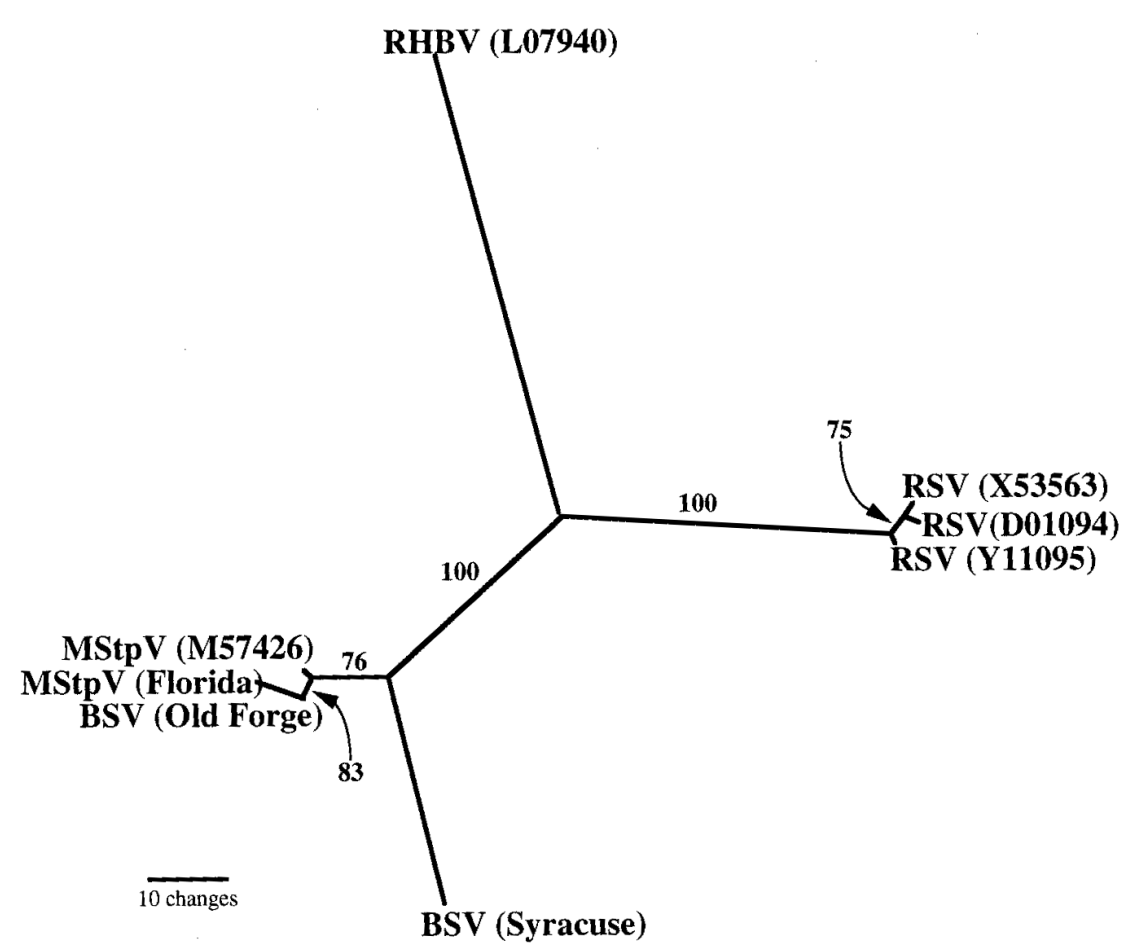

Fig. 3. An unrooted phylogram comparing the sequences of the RNA-3 segments of Maize stripe virus (MStpV), Rice hoja blanca virus (RHBV), and Rice stripe virus (RSV) (GenBank accession numbers in parentheses) with those of the black spruce virus (BSV) sequences derived from the trees located at Old Forge and Syracuse, New York, by reverse transcription-polymerase chain reaction (RT-PCR) amplification using MStpV primers to the $\mathrm{p} 3$ open reading frame of MStpV vRNA 3. Only one most parsimonious tree was found using a branch and bound search on PAUP* (14). The tree is 269 steps $(\mathrm{CI}=0.93, \mathrm{RI}=0.91)$ and was generated using 314 nucleotide positions including gaps (107 informative characters). Bootstrap values (500 replications) are indicated on the branches.

informative characters). The viral RNA sequence from the Syracuse tree (BSVSYR) is approximately $17 \%$ different from MStpV and the viral RNA sequence from the Old Forge tree (BSV-OF), but sequences from MStpV and BSV-OF were approximately 98\% homologous (Fig. 4). BSV-OF (accession AF177864), BSV-SYR (accession AF177865), and MStpV-Florida (accession AF177863) sequences were deposited with GenBank.

IC-PCR. Attempts to amplify the viral RNA directly from crude needle extracts using an antiserum to MStpV for the immunocapture step, followed by two rounds of nested PCR, were unsuccessful; whereas MStpV RNA from infected corn tissue was amplified following immunocapture and one or two rounds of PCR (data not shown).

Prevalence and host range. The characteristic 399-bp band was detected following the second round of PCR in needle samples from one black spruce tree located at Lost Pond Bog in the Cranberry Lake watershed, Cranberry Lake, New York (data not shown). The PCR product has not yet been sequenced. The virus was not detected in the other black spruce trees or conifer species sampled.

\section{DISCUSSION}

We have demonstrated the presence of two distinct virus isolates (BSV-OF and that it is a member of the Tenuivirus. Particle morphology is consistent with the coiled, rigid-rod configuration observed frequently in RSV but rarely in MStpV preparations (7). But unlike RSV, the rigid-rod configuration did not disappear in $\mathrm{CsCl}$ gradients (Fig. 1). The buoyant density of the spruce virus $\left(1.39 \mathrm{~g} / \mathrm{cm}^{3}\right)$ is greater than that of other tenuiviruses $\left(1.28 \mathrm{~g} / \mathrm{cm}^{3}\right)$. Similarly, the branched filaments characteristic of RSV were not observed. The $A_{260 / 280}$ of BSV-OF (1.44) is within the range of tenuiviruses (1.29 to 1.6) (7). Particle diameter is similar to
RGSV (9), and like RGSV, the 8- to 9-kb ssRNA segment (vcRNA1), which is believed to code for the viral RNA polymerase and is characteristic of most tenuiviruses (13), was not detected (Table 1). The purification protocol resulted in many apparently fragmented virions (Fig. 1) and may account for our inability to detect the largest RNA segment. Nonetheless, the size of detectable RNA segments, the presence of a 1.3-kb RNA segment, and sequence homology with respect to the $\mathrm{p} 3$ ORF of MStpV suggest that BSV-OF is closely related to MStpV.

However, both BSV-OF and BSV-SYR also differ from MStpV; neither virus RNA was amplified by RT-PCR using primers to the nucleocapsid (pc3) ORF of MStpV vcRNA 3, even at low annealing temperatures. In addition, BSV-OF and BSV-SYR viral RNA did not amplify by IC-PCR using antiserum to $\mathrm{MStpV}$ and the p3 primer set. Thus, both viruses differ from MStpV with respect to their nucleocapsids. Also, the RNPs of the black spruce viruses differ from those of MStpV as discussed above. Finally, we were unable to detect the 8-kb RNA segment typical of MStpV.

At present, BSV-OF and BSV-SYR can be detected only by RNA extraction of needle tissue followed by RT and two rounds of nested PCR amplification. Production of an antiserum is essential to permit the development of sensitive serological assays (e.g., IC-PCR), which would facilitate detection of the virus in spruce and potential insect vectors, and to determine serological relationships to known tenuiviruses. Although the virus purification protocol utilized was similar to that of several tenuivirus protocols, virus yield from black spruce needles was only 1 to 3 $\mathrm{mg} / \mathrm{kg}$ of needle tissue compared with yields of 10 to $300 \mathrm{mg} / \mathrm{kg}$ of leaf tissue for most tenuiviruses (7). To permit antiserum production, as well as to further characterize viral RNAs and proteins, the purification protocol first must be improved.

To our knowledge, this is the first report of a tenuivirus in a nongrass host. Tenuiviruses have relatively narrow host ranges within the grasses, are primarily tropical to subtropical in geographic distribution, and are transmitted in a persistent manner by Delphacid planthoppers (7). The host range, geographical distribution, and vectors of the black spruce tenuiviruses are unknown.

\section{ACKNOWLEDGMENTS}

We thank R. Hamelin and V. Jacobi of the Canadian Forest Service for providing the black spruce seedlings. MStpV antiserum and virusinfected corn tissue were kindly provided by $\mathrm{T}$. Lanker and R. Louie (Ohio Agric. Res. \& Dev. Center, Wooster, OH). We acknowledge the help of A. Awori, H. Nuttall, A. Schembari, K. Haus, T. Diana, and S. Hetey for assistance with virus purification and PCR, and Lijun Ma for help with cycle sequencing. We also thank B. Falk and V. Jacobi for reviewing earlier drafts of the manuscript. 


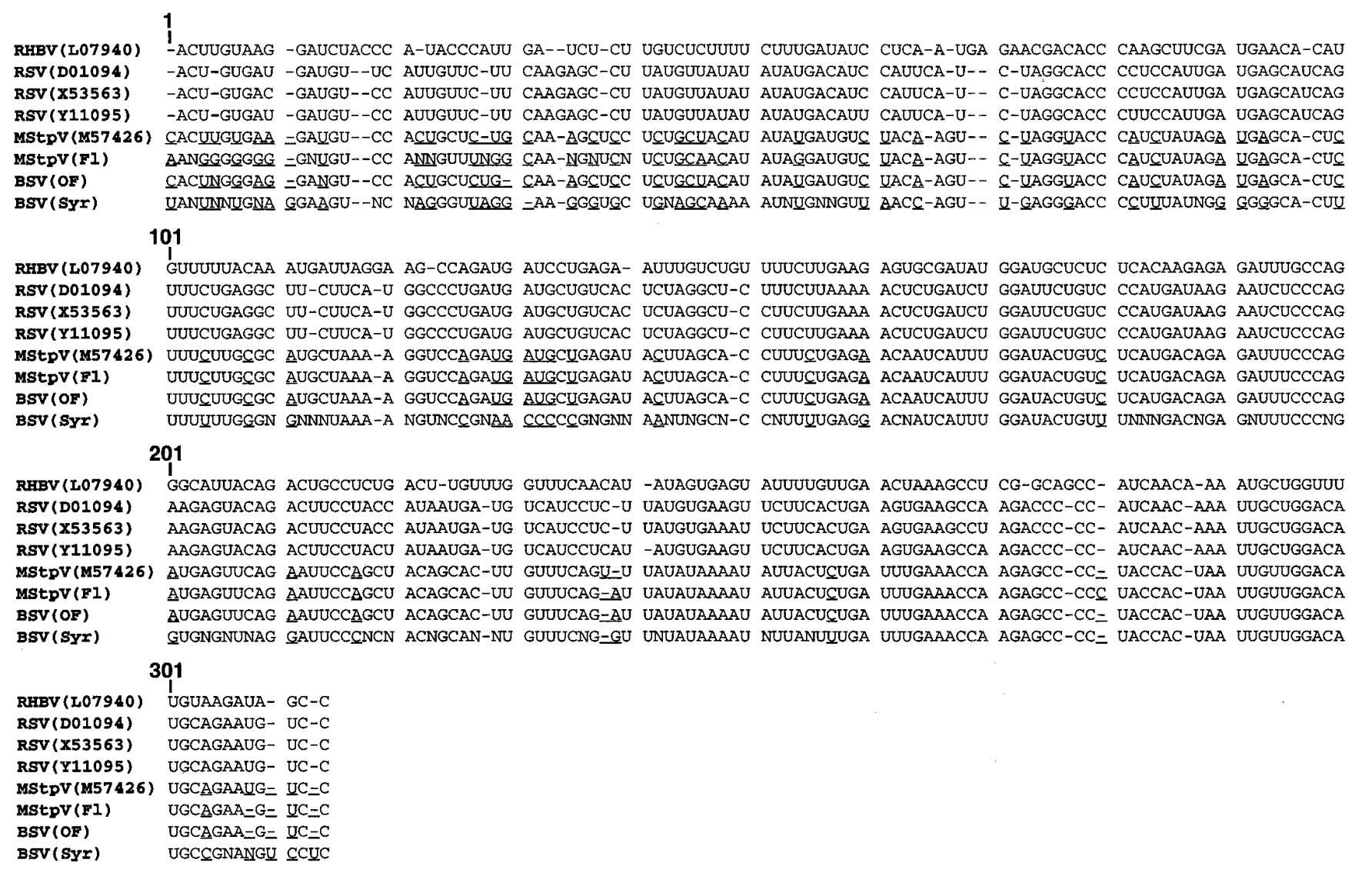

Fig. 4. Sequence alignment used in the phylogenetic analysis in Figure 3. Gaps were introduced to allow complete alignment. Ambiguous nucleotides are indicated as "N." Nucleotide position numbers are indicated at the beginning of each block of sequences. The total shown is 314 nucleotide positions, including gaps. Position 1 corresponds to position 150 and position 314 corresponds to position 444 of the Maize stripe virus (MStpV) (GenBank accession no. 57426) vRNA 3. RHBV = Rice hoja blanca virus, RSV = Rice stripe virus, MStpV $(\mathrm{FL})=\mathrm{MStpV}$ isolate from Florida, BSV $(\mathrm{OF})=$ black spruce virus (Old Forge isolate), and BSV (SYR) = BSV (Syracuse isolate). Differences among the BSV and MStpV sequences are underlined.

\section{LITERATURE CITED}

1. Bachand, G. D., Castello, J. D., Schaedle, M., Stehman, S. V., and Livingston, W. H. 1996. Effects of tomato mosaic tobamovirus infection on red spruce seedlings. Can. J. For. Res. 26:973-981.

2. Biddle, P. G., and Tinsley, T. W. 1968. Virus diseases of conifers in Great Britain. Nature 219:1387-1388.

3. Castello, J. D., Bachand, G. D., Fillhart, R. C., and Varga, M. 1998. Evidence of a putative Tenuivirus in black spruce. (Abstr.) Eur. J. For. Pathol. 28:75-76.

4. Cech, M., Kralik, O., and Blattny, C. 1968. Rod-shaped particles associated with virosis of spruce. Phytopathology 51:183-185.

5. Falk, B. W., and Tsai, J. H. 1998. Biology and molecular biology of viruses in the genus Tenuivirus. Annu. Rev. Phytopathol. 36:139163.

6. Flachmann, M., Lesemann, D.-E., Frenzel, B., and Koenig, R. 1990. Isometric virus-like particles in Abies alba Mill. and other Abies species: Partial purification and improved detection by means of immunoelectron microscopy. J. Phytopathol. 129:193-202.

7. Gingery, R. E. 1988. The Rice Stripe Virus Group. Pages 297-329 in: The Plant Viruses. Vol. 4. R. G. Milne, ed. Plenum Press, New York.

8. Gingery, R. E., Nault, L. R., and Bradfute, O. E. 1981. Maize stripe virus: Characteristics of a member of a new virus class. Virology 112:99-108.

9. Iwasaki, M., Nakano, M., and Skinkai, A. 1985. Detection of rice grassy stunt virus in planthopper vectors and rice plants by ELISA. Ann. Phytopathol. Soc. Jpn. 51:249.

10. Jacobi, V., Bachand, G. D., Hamelin, R. C., and Castello, J. D. 1998. Development of a multiplex immunocapture RT-PCR assay for detection and differentiation of tomato and tobacco mosaic tobamoviruses. J. Virol. Methods 74:167-178.

11. Kingston, R. E. 1997. Preparation and analysis of RNA. Suppl. 37, Ch. 4, Sec. 4.9.2 in: Current Protocols in Molecular Biology, 1998. F. M. Ausubel, R. Brent, R. E. King- ston, D. D. Moore, J. G. Seidman, J. A Smith, and K. Struhl, eds. John Wiley \& Sons, New York.

12. Morales, F. J., and Niessen, A. I. 1983. Association of spiral filamentous viruslike particles with rice hoja blanca. Phytopathology 73:971-974.

13. Ramirez, B.-C., and Haenni, A.-L. 1994 Molecular biology of tenuiviruses, a remarkable group of plant viruses. J. Gen. Virol. 75:467-475.

14. Swofford, D. 1998. PAUP* Ver. 4d63. Smithsonian Institution, Washington, DC.

15. Tavantzis, S. M. 1983. Improved purification of two potato carlaviruses. Phytopathology 73:190-194.

16. Tsai, J. H. 1975. Occurrence of a corn disease in Florida transmitted by Peregrinus maidis. Plant Dis. Rep. 59:830.

17. Wilkins, T. A., and Smart, L. B. 1996. Isolation of RNA from plant tissue. Pages 21-41 in: A Laboratory Guide to RNA: Isolation, Analysis, and Synthesis. P. A. Krieg, ed. Wiley-Liss, New York. 